\title{
User's Perception of the Relevance of Courtyard Designs in a Modern Context: A case of Traditional Pol Houses, Ahmedabad
}

\author{
Gaurav Gangwar ${ }^{1,2, *}$, Prabhjot Kaur ${ }^{3}$ \\ ${ }^{1}$ Research Fellow, Faculty of Planning and Architecture, IKG Punjab Technical University Jalandhar, Punjab, India \\ ${ }^{2}$ Associate Professor, Chandigarh College of Architecture, Chandigarh Administration, Chandigarh (UT), India \\ ${ }^{3}$ Director, School of Built Environment, IKG PTU Mohali Campus II, Sector 115 Mohali, Punjab, India
}

Received April 20, 2020 ; Revised May 21, 2020; Accepted June 23, 2020

Copyright $\subseteq 2020$ by authors, all rights reserved. Authors agree that this article remains permanently open access under the terms of the Creative Commons Attribution License 4.0 International License

\begin{abstract}
Courtyard designs were prevalent in India and around the world for ages because of their utility as a climate modifier, a space for social interaction, and a connecting area for the entire house. The globalization and liberalization of India in 1990 has changed people's lifestyles and resulted in courtyard designs losing their significance. They prefer living in modern housing based on western architecture. However, there is a considerable population still residing in courtyard houses. This study explores the benefits of the traditional courtyard houses and their relevance in the present context. The survey questionnaire aims to know the user's perceptions of the courtyard design, such as spatial, environmental, and behavioral aspects. The data is analyzed across various parameters of courtyard design, such as thermal comfort, natural light, visual connection, privacy, security, activities during the day and different seasons, etc. The results show that people like courtyards because they provide thermal performance during peak summer, natural light, privacy, security, visual connection, space for daily and seasonal activities. This paper recommends designs for courtyards based on the literature review and the analysis of the user's perception.
\end{abstract}

Keywords Globalization, Courtyard House, Climate Modifier, Environmental, Behavioral, Spatial, Thermal Comfort, Natural Light

\section{Introduction}

Paul Oliver has written in his book "Dwellings: The House Across the World" that, "Courtyard houses have an ancient history: examples have been excavated at Kahun, in Egypt, that are believed to be 5000 years old, while the Chaldean City of Ur, dating from before 2000 BC, was also comprised houses of this form." The origin of the courtyard still needs to be explored in history. However, according to Hinrich, Oliver, Schoenauer, and Sullivan, the courtyard architecture has evolved from the fenced compound dwellings of the first agrarian communities and the encampments of the nomadic tribes. The four ancient civilizations of the world, Mesopotamia, Indus Valley, Egypt, and China, along with Romans and Greeks, were using courtyard form as a prominent design feature in their built structures. [1]

Houses that belong to the erstwhile Indus Valley Civilization in India (2000-1500 B.C.E.) also boasted courtyards. The famous archeologist Sir John Marshall describes the courtyard houses as follows: "To the right of the porter's lodge, a short passage led to the central courtyard of the house, which was open to the sky and provided light and air to the rooms grouped about it on both the ground and upper floors. And here, let me say parenthetically, that the principle of the open courtyard encompassed by chambers was just as fundamental to house-planning at Mohenjo-daro as it was throughout the rest of the prehistoric and historic Asia, and as it has continued to be in India until the present day." [2]

Traditional courtyard houses are indigenous in India. They have been developed through the ages by trial and error to a state of general acceptance. They seem to have fulfilled the needs of their inhabitants across functional requirements, socio-cultural and religious demands, micro-climatic and internal thermal environment performance, energy-saving, and economic means. They have desirable architectural qualities of their own, both internally and externally. Even with limited financial means of the owner-occupier and the limitations of 
building technologies at the time, they could meet said objectives. [3]

The new economic policy of liberalization in $1990 \mathrm{had}$ led to globalization in India. It was considered an economic integration phenomenon that was no longer just political or economic, but a cultural phe-nomenon as well. Increasing interaction and integration across borders due to globalization diminish differences between nations, causing global ideas, practices, and norms to dilute local cultures. [4] Due to globalization, contemporary apartments, high-rise housing, and houses without courtyard replaced by the traditional courtyard houses. They could fit anywhere irrespective of climate, culture, building materials, etc.

Traditional courtyard houses have lost their significance in India for the past few decades, and there are specific reasons for it. People are more concerned about their image than the integration of space, and they reject the blind walls and doors. The building bye-laws have restricted the courtyard option due to front and rear setbacks for smaller sized plots. The family lounge has replaced the courtyard due to a transition of joint families into nuclear families. The need for better utilization of ground coverage and F.A.R. has led to apartment housing replacing courtyard houses. People prefer air-conditioned space for comfort and prefer shorter distances rather than crossing open spaces. [5]

It is concluded that courtyard designs were very relevant in the past due to the numerous benefits it offered to the users. Influences of western architecture building typologies such as apartments and high-rise housing have led to change in the housing scenario. People seem to be more interested in these new modern ways of living. There is a significant population still living in these traditional courtyard houses. It is essential to investigate if these traditional courtyard houses still offer benefits to people living in it and how relevant it is in the present context.

\subsection{Aim of the Project}

To analyze the user's perception of the relevance of courtyard design in the present context of the Post-Global Era.

\subsection{Objectives}

a) To identify the various parameters of courtyard design through literature review.

b) To categorize the parameters into themes for conceptual understanding.

c) To check the relevancy of every parameter and aspect of courtyard design in a modern context.

d) To propose the recommendations based on literature review and quantitative analysis of every parameter and theme.

\section{Courtyard as Central Design Features of Pol Houses}

Pol houses are narrow on the front, and the streets are usually narrow too. Because of the shorter length of the street, these houses have narrow front as per the principles of neighborhood design. They typically do not have an open space in front, back, or side like modern houses. Pol houses have the entire plot built, and adjacent pol houses share two to three walls. This structure results in a very dense environment. In 1971, the population density was 225,000 per square mile. [6]

The otala (verandah) is a platform raised from the street and often used for siting and religious activities. It is a transition area between the street and the house. There is space for washing utensils and clothes on one side of this otala space. This space is semi-covered with columns, and the upper balcony space projection shades the otala area. $[6,7]$

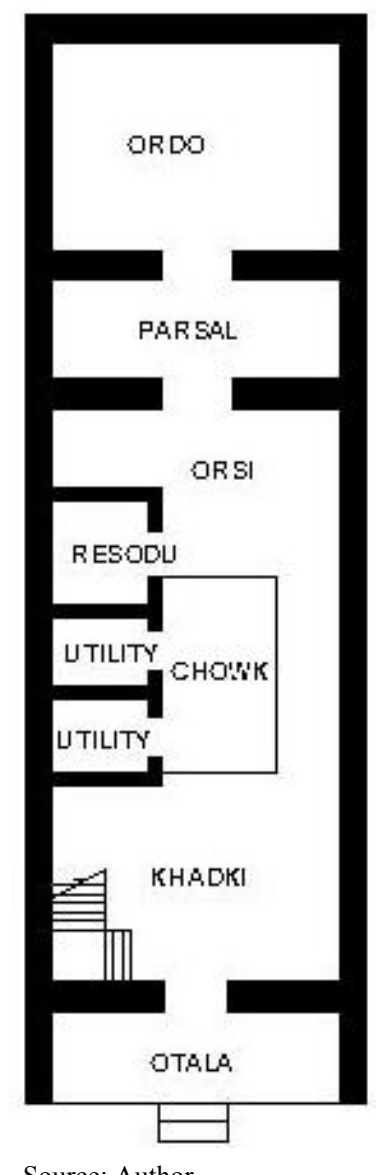

Source: Author

Figure 1. Ground Floor Plan of Typical Pol House

The courtyard is a central feature of Pol houses. All interior spaces can be a divide into two categories, as follows:

\subsection{Courtyard or Chowk}

It is a crucial feature of the house, and all the domestic 
activities revolve around the chowk. The courtyard is the only open space and allows natural light and ventilation in the house. The design enables it to act as a climate modifier for the house. The windows of the rooms on the upper floors open towards the courtyard. Because of this, there is an ample amount of natural light and ventilation in these rooms. The chowk acts as a physical connecting space for all spaces on the ground floor. It also provides a visual connection of the ground floor to the upper floor. As per Vastu Purush Mandala, the courtyard is a central open space and the place for Brahma. This space is bringing occupants in contact with supernatural powers and the deity as per Hindu Mythology. The rainwater tank of adequate size is always present underneath the chowk, and the opening of this tank is placed in verandah nearby. [6-8]

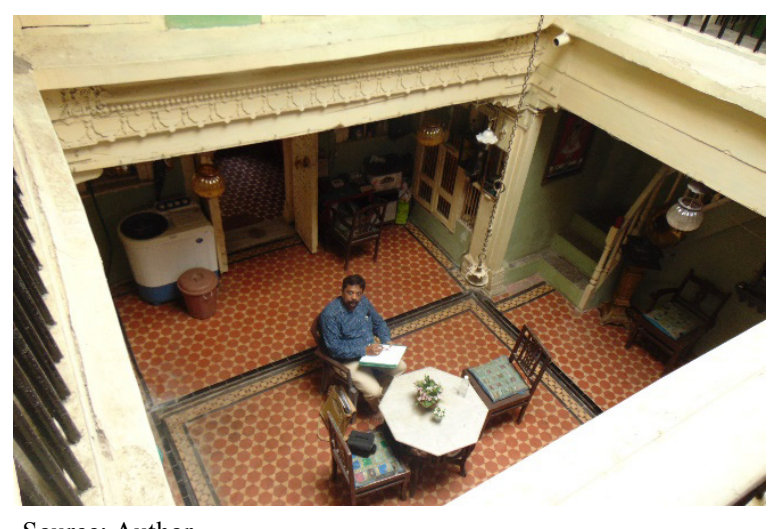

Source: Author

Figure 2. View of Courtyard from the first floor

\subsection{Surrounding Spaces around the Courtyard}

a) Khadki/Bhaitak (Living space): This is the front portion and the reception of the house. Visitors use this space for formal purposes, and it generally has a traditional swing installed. [7]

b) Resodu (Kitchen): The kitchen links the courtyard, verandah, and parsal. The kitchen placement is crucial as many kitchen activities always extend to the interconnected spaces. [7]

c) Orsi (Verandah): This space is near the chowk, and all spillover activities of chowk occur in this space. It is a semi-open space. [7]

d) Parsal (Family space): This is considered a private space for all family activities. It acts as a dining area for the family or as an extension of the kitchen. There is a swing placed for sitting purposes in the space. $[6,7]$

e) Ordo (Rooms): This is the innermost part of the house, and often there are two or more rooms built. These rooms act as bedrooms or storage space for granary. [7]

\section{Literature Review}

The authors have done extensive research on the courtyard design. Most of the available research comes from qualitative analysis of various courtyard design parameters, and only a few studies are available on quantitative analysis. Listed below are a few critical studies:

1. Aisha Kabir Marafa and Halil Zafer Alibaba state that the survey questionnaire assesses the user perception of the courtyard as a thermal regulator. The carefully designed questionnaire used to conduct this study aims to determine how, when, what, and why people use a courtyard. The responses analyzed for descriptive statistics, namely the mean (M) and percentage (\%), use SPSS version 2.1. The analysis indicates that $85.7 \%$ of respondents appreciate the presence of the courtyard, and the remaining $14.3 \%$ are indecisive. Most of the respondents (64\%) prefer to use the courtyard as a sitting space, and the rest (36\%) use it as a connecting space. Half the residents $(50 \%)$ use the courtyard in the evening, and around $35.7 \%$ use it in the afternoon. The majority of respondents $(85.7 \%)$ agree that the courtyard improves the indoor air quality while the rest (14.3\%) are indecisive. $42.9 \%$ of respondents use courtyard in summers, $28.9 \%$ in winter, and $28.6 \%$ in summer as well winter. Most of the respondents $(78.6 \%)$ feel that the courtyard reduces the amount of heat during summer. $57 \%$ of residents use shading devices, while $43 \%$ use electrical appliances in summer. [9]

The above results are indicating the courtyards are still relevant in a modern context as the courtyard are acting as a thermal regulator and create comfort for residents.

2. Adi Ainurzaman Jamaluddin, Hazreena Hussein, and Kauthar Md. Tahir states that a survey questionnaire was conducted at two residential colleges in the University of Malaya to assess the resident's satisfaction level towards an existing courtyard. The survey questionnaire consists of questions about overall quality and layout of the building, lighting quality (natural daylight), thermal comfort, indoor air quality, overall comfort level, and the influence of overall building conditions on the productivity. In the first round of the study, 266 residents responded, and in the second round, 181 residents responded to the survey questionnaire. The questionnaire adopts a Likert scale $(+2,+1,0,-1,-2)$. These studies indicate that the location and condition of the courtyard influence the satisfaction level of residents. The natural daylight and ventilation through the courtyard are essential factors for their comfort. The conditions of the courtyard, such as grass, shrubs, and glass on top, make the courtyard a place for social interaction. It also improves the overall comfort level, which increases the productivity of residents. [10]

3. M. Susan Ubbelohde describes the thermal Behavior of Pol Houses in different seasons as given below: 


\section{Thermal Behavior in Summer (Mid-March to Mid-June):}

The bioclimatic chart for Ahmedabad clearly shows that there is a need for thermal strategies in summer months from mid-March to June. Pol houses are well-sited; long walls of the house are common with no sun radiation exposure, and short walls facing the street are shaded due to the narrow street section. The wall facing streets are using wood as the primary material, which does not gain too much solar heat due to its low thermal capacity. The exceptionally designed chowk or courtyard cuts the solar radiation in summers due to its tall and narrow shape through mutual shading. In most houses, the interior elevation of the courtyard also has wooden detail, which further reduces solar heat gain. The rainwater harvesting tank is always under the courtyard, and the specially designed courtyard's floor tiles gain less heat. The washing of clothes and utensils is also significant activity in the courtyard and responsible for evaporative cooling. The windows of the house in the courtyard are open at night to attract the cold wind and are closed during the day to minimize solar heat gain. Most of the time, the ground floor is used during the day because the upper floors are very hot due to maximum solar heat gain through roof and terraces. The upper floors offer a cool area to sleep at night, along with other activities. [6].

\section{Thermal Behavior in Winter (Mid-September to Mid-March):}

The upper floor in winter gets maximum solar radiation through roofs. The orientation of windows, facing the street mostly in the south direction, allows the sun's penetration inside the upper floors. The sizes of the courtyard are small, so the sun does not penetrate the ground floors during winter. However, the courtyard act as a shield to protect from cold winter winds. [6]

\section{Thermal Behavior in Monsoon (Mid-June to Mid-September):}

The temperature is not high as compared to summer but still sufficient to create an uncomfortable hot and humid condition. The warm and humid conditions during monsoon become problematic because the houses have a minimum opening, which does not allow air to circulate. The courtyard is not a very comfortable place in monsoon due to rain, and many residents try to cover the courtyard through plastic sheets. [6]

In conclusion, houses with well-designed courtyards display exceptional thermal Behavior during the summer season. The houses are a little bit comfortable in winter, not due to design features, but because winters are not critical. The monsoon season is worst for the pol houses, and residents face many problems in this season. [6]

4. Mihir Vakharia describes how the presence of a courtyard affects thermal characteristics within a space. There are comparisons of various parameters of thermal characteristics of three Pol houses with courtyard and without courtyard by using Computational Fluid Dynamics. These houses are approximately 100 years old and three-storied structure in Moti Hamam ni Pol. The field data collection under various parameters such as relative humidity, air temperature, air velocity, globe temperature, and surface temperature happened in April 2012 for seven days. The weather data collection occurred between April 2012 to July 2012. [11]

The study revealed that the incidence of solar radiation on the rooftop is the primary source of heat responsible for raising the exterior surface temperature of the envelope. The ground floor courtyard in all three houses is shaded throughout the day and acts as a ventilation shaft and hence improves the thermal environment. The presence of the courtyard also improves the relative humidity, indoor air quality, and natural lighting. [11]

5. Niti Bhatt describes various elements and functions of Chowk or Courtyard. The pol houses wrapped in dense fabric result in allowing natural light to enter the house from two surfaces - the front façade and the top, i.e., chowk. The natural light entered through the courtyard has gradation - light to dark, as one moves away from the source. Interior volumes of rooms such as parsal, resodu, khadki, ordo, raveshi, etc. draw light from the core. It gets more diffused as one moves away from the core. Chowk emphasizes the character of building through natural light, which brings texture to surfaces by creating light and shade. [12]

6. Nibedita Das describes the psychosocial, cultural, climate, and symbolic-religious benefits. The psychosocial benefits incorporate the sense of enclosure and privacy. The courtyard acts as a multipurpose "outdoor room" like kitchen extension in the morning and living area for guests in the evening. It is a safe place for children under the elder's supervision, which also provides acoustical privacy free from the noise of the street. The cultural benefits include the adaptability of a courtyard in different cultures. Occidental and oriental cultures use courtyard differently. The occidental focus on social values, wealth, social status, and too much decoration in their courtyard façade. The oriental emphasis on the functional use of the courtyard to maximum utilization. The symbolic and religious benefits involve the courtyard's symbolization of inwardness and feminism, an oasis in the desert, a fragment of nature inside the house, a concentration of light, wind, sound, and water. The courtyard in the Hindu religion follows the cosmic square of theology, Vastu Purusha Mandala. It is a part of daily religious rituals 
performed around the Tulsi plant in the courtyard. [1]

Extensive research concludes that there is no study available on the user's perception of courtyard designs for the Pol houses of Ahmedabad. This study will undoubtedly create new knowledge in the field of architecture.

\section{Methodology}

This research involves the quantitative analysis, rating of various variables, and limited availability of respondents. Hence, the closed-ended survey questionnaires are the best suitable method to conduct this research. It is further to reinforce that the survey questionnaire method has been adopted in two similar studies, as mentioned in the Literature review section authored by Aisha Kabir Marafa and Adi Ainurzaman Jamaluddin. $[9,10]$

The survey questionnaire method turns out to be the best-suited approach for this study.

\subsection{Parameters for Study}

As per the literature review, there are three classification parameters for the courtyard design. They are as follows:

Table 1. Parameters of courtyard design

\begin{tabular}{|c|c|l|}
\hline & $\begin{array}{c}\text { Aspects of } \\
\text { courtyard design }\end{array}$ & \multicolumn{1}{|c|}{ Parameters of courtyard design } \\
\hline 1 & Spatial aspects & $\begin{array}{l}\text { Size, location, the proportion of } \\
\text { courtyard, visual connection }\end{array}$ \\
\hline 2 & $\begin{array}{c}\text { Environmental } \\
\text { aspects }\end{array}$ & $\begin{array}{l}\text { Thermal comfort, ventilation, and } \\
\text { natural light }\end{array}$ \\
\hline 3 & $\begin{array}{c}\text { Behavioral activities, social gathering, } \\
\text { aspects }\end{array}$ & $\begin{array}{l}\text { preference of activities in different } \\
\text { seasons and different time of day } \\
\text { within a courtyard, privacy, and } \\
\text { security }\end{array}$ \\
\hline
\end{tabular}

\subsection{Designing the Survey Questionnaire}

The survey questionnaire has been developed based on a research paper titled "User Perception of Courtyard as a Thermal Regulator in Households, Famagusta, Cyprus "by Aisha Kabir Marafa and Halil Zafer Alibaba [9]. There are 20 questions designed, most of which were related to spatial aspects, environmental aspects, and behavioral aspects of courtyard design to meet the research's desired objectives. For a rating of answers to questions, there is a usage of the five-point Likert scale and itemized scale. The number of questions for every parameter is designed, according to the importance and specific need of parameter.

\subsection{Sample Design}

The study involves a convenient sampling method because the availability of courtyards with heritage gradings is limited, and there are specific criteria for selecting the same. The main criteria for the selection of the sample were the size of the courtyard and the heritage grading of Pol house.

There are mainly three different sizes of the courtyards, i.e., less than $5 \mathrm{sqm}, 5-10 \mathrm{sqm}$, and more than $10 \mathrm{sqm}$. 3-4 respondents selected for each house on average for the equal representation of all gender and age groups. Aisha Kabir Marfa [9] has chosen 30 respondents in her research paper. A total of 34 houses have been selected. Out of these 34, 17 have courtyards of size less than 5 sqm, 13 have courtyards of size 5-10 sqm, and the remaining 4 have courtyards of size more than $10 \mathrm{sqm}$. In total, 106 respondents have been surveyed from these 34 houses. $70 \%$ of respondents are living in 100 years or older houses. 27 out of 34 houses are heritage graded by Ahmedabad Municipal Corporation, which ensures these are the traditional Pol houses. All 34 courtyard samples have been collected from 19 Pols widely spread across the walled city of Ahmedabad.

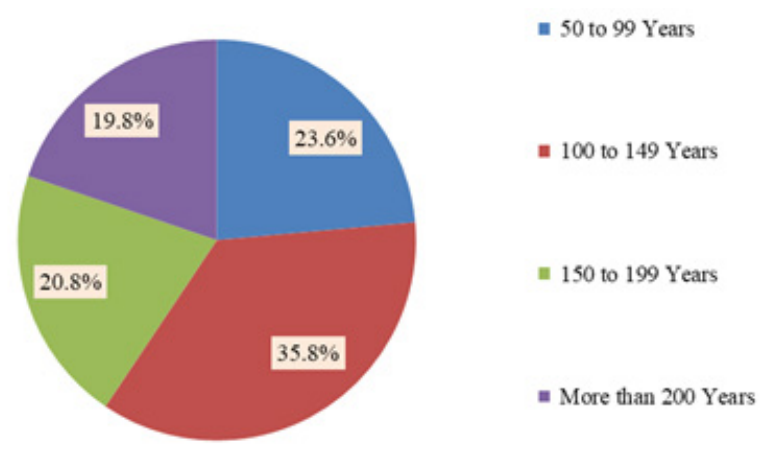

Figure 3. Age of Courtyard house

It is essential to mention that all selected courtyard houses still have the original courtyard design's unique traditional character except for minor changes, e.g., floorings, and so forth.

\subsection{Data Organization and Reliability Test}

Microsoft Excel is used for data organization. Every row was designated to one record (one respondent), and each variable was placed under different columns. The author has collected and organized the data. This data has been re-checked with the original survey questionnaire to confirm that there is no missing or erroneous data placed in this excel sheet. Data points were examined for their reliability before conducting a detailed statistical analysis and hypothesis testing. Data reliability and validity checks were performed using Cronbach's Alpha Test, where Cronbach's alpha is a measure of internal consistency (reliability). For this test, all the key variables and essential variables of the study were considered. The following table presents Cronbach's Alpha test results. 
Table 2. Cronbach Alpha Test: Summary

\begin{tabular}{|c|c|c|c|}
\hline \multicolumn{2}{|c|}{} & $\mathrm{N}$ & $\%$ \\
\hline \multirow{3}{*}{ Cases } & Valid & 106 & 100.0 \\
\cline { 2 - 4 } & Excluded & 0 & 0.0 \\
\cline { 2 - 4 } & Total & 106 & 100.0 \\
\hline
\end{tabular}

a. Listwise deletion based on all variables in the procedure.

Table 3. Reliability Statistics

\begin{tabular}{|c|c|}
\hline Cronbach's Alpha & No. of Items \\
\hline 0.834 & 67 \\
\hline
\end{tabular}

The reliability and internal data consistency are excellent as the alpha value is 0.834 , which is more than 0.75 . Hence, it is decided to do a further detailed analysis to achieve the research objectives set and hypothesis framed.

\subsection{Statistical Analysis}

SPSS Version 20.0 (Statistical Package for Social Sciences) is used for analyzing the data.

\section{Analysis and Discussions}

The entire data analysis is categorized into four parts; the first one is a demographic analysis of respondents to understand the respondents, and the three-part consist of the three aspects of courtyard design, such as spatial, environmental, and behavioral aspects of courtyard design. Additionally, respondents rated the questions, as mentioned in the tables below.

\subsection{Demographic Analysis of Respondents}

Table 4. Demographics of respondents

\begin{tabular}{|c|c|c|c|}
\hline Question & Responses & Overall & Percentage \\
\hline \multirow{3}{*}{ Age } & $\begin{array}{c}\text { Young Adult (16 to } \\
\text { 30 years) }\end{array}$ & 20 & $18.9 \%$ \\
\cline { 2 - 4 } & $\begin{array}{c}\text { Middle Adult (31 to } \\
\text { 50 years) }\end{array}$ & 30 & $28.3 \%$ \\
\cline { 2 - 4 } & $\begin{array}{c}\text { Senior Adult (More } \\
\text { than 50 years) }\end{array}$ & 56 & $52.8 \%$ \\
\hline \multirow{3}{*}{ Gender } & Male & 63 & $59.4 \%$ \\
\cline { 2 - 4 } & Female & 43 & $40.6 \%$ \\
\hline
\end{tabular}

As observed in Table 4, males $(59.4 \%)$ are slightly higher than females $(40.6 \%)$, and $52.8 \%$ of respondents belong to age for more than 50 years. Many old age people are living in these houses alone.

\subsection{Environmental Aspects of Courtyard Design}

\subsubsection{Thermal Comfort}

As discussed in the literature review, thermal comfort depends on three parameters, i.e., temperature, humidity, and air movement (ventilation). The summers are critical in Ahmedabad.

Q: Ranking of Thermal Comfort: summer, winter, and monsoon

Table 5. Thermal Comfort in various seasons

\begin{tabular}{|c|c|c|c|}
\hline Question & Responses & Overall & Percentage \\
\hline \multirow{5}{*}{ Summer } & Very uncomfortable & 7 & $6.6 \%$ \\
\hline & Slight uncomfortable & 6 & $5.7 \%$ \\
\hline & Comfortable & 0 & $0 \%$ \\
\hline & Slight comfortable & 21 & $19.8 \%$ \\
\hline & Very comfortable & 72 & $67.9 \%$ \\
\hline \multirow{5}{*}{ Winter } & Very uncomfortable & 7 & $6.6 \%$ \\
\hline & Slight uncomfortable & 25 & $23.6 \%$ \\
\hline & Comfortable & 0 & $0 \%$ \\
\hline & Slight comfortable & 55 & $51.9 \%$ \\
\hline & Very comfortable & 19 & $17.9 \%$ \\
\hline \multirow{5}{*}{ Monsoon } & Very uncomfortable & 2 & $1.9 \%$ \\
\hline & Slight uncomfortable & 25 & $23.6 \%$ \\
\hline & Comfortable & 1 & $0.9 \%$ \\
\hline & Slight comfortable & 66 & $62.3 \%$ \\
\hline & Very comfortable & 12 & $11.3 \%$ \\
\hline
\end{tabular}

As observed in Table 5, 87.7\%, 69.8\%, and 74.5\% of respondents are comfortable in summers, winters, and monsoons, respectively. As observed in Table 13, people are very comfortable in summers as compared to winter or monsoon. Hence courtyards are not much uncomfortable in any season, but the courtyards are very comfortable in summers as compared to winter or monsoon.

Q: Do you feel that the courtyard is providing ventilation in all rooms?

Table 6. Ventilations in all rooms

\begin{tabular}{|c|c|c|c|}
\hline Question & Responses & Overall & Percentage \\
\hline \multirow{4}{*}{$\begin{array}{c}\text { Ventilations } \\
\text { in all rooms }\end{array}$} & Strongly Disagree & 0 & $0.0 \%$ \\
\cline { 2 - 4 } & Disagree & 6 & $5.7 \%$ \\
\cline { 2 - 4 } & Undecided & 0 & $0.0 \%$ \\
\cline { 2 - 4 } & Agree & 31 & $29.2 \%$ \\
\cline { 2 - 4 } & Strongly Agree & 69 & $65.1 \%$ \\
\hline
\end{tabular}

As observed in Table 6, 94.3\% agree, and 5.7\% disagree that the courtyard is providing ventilation in all rooms. It is concluded that courtyards are excellent for providing ventilation in all rooms.

Q: How do you avoid the Heat during summer in a courtyard house? 
Table 7. Avoid of Heat in summer

\begin{tabular}{|c|c|c|c|}
\hline Question & Responses & Overall & Percentage \\
\hline \multirow{4}{*}{$\begin{array}{c}\text { Nothing is } \\
\text { required }\end{array}$} & Never & 34 & $32.1 \%$ \\
\hline & Rarely & 4 & $3.8 \%$ \\
\hline & Sometimes & 4 & $3.8 \%$ \\
\hline & Always & 64 & $60.4 \%$ \\
\hline \multirow{5}{*}{ Desert Cooler } & Never & 88 & $83.0 \%$ \\
\hline & Rarely & 6 & $5.7 \%$ \\
\hline & Sometimes & 8 & $7.5 \%$ \\
\hline & Often & 2 & $1.9 \%$ \\
\hline & Always & 2 & $1.9 \%$ \\
\hline \multirow{4}{*}{$\begin{array}{c}\text { Air } \\
\text { Conditioning }\end{array}$} & Never & 76 & $71.7 \%$ \\
\hline & Rarely & 13 & $12.3 \%$ \\
\hline & Sometimes & 15 & $14.2 \%$ \\
\hline & Often & 2 & $1.9 \%$ \\
\hline \multirow{4}{*}{$\begin{array}{c}\text { Covering of } \\
\text { cloth }\end{array}$} & Never & 76 & $71.7 \%$ \\
\hline & Rarely & 2 & $1.9 \%$ \\
\hline & Sometimes & 21 & $19.8 \%$ \\
\hline & Always & 7 & $6.6 \%$ \\
\hline
\end{tabular}

As observed in Table 7, there are $60.4 \%$ respondent feel that nothing is required for; the $83 \%$ respondents feel that they do not need a desert cooler, $71.7 \%$ feel that they do not require air conditioning, $71.7 \%$ feel that they do not require the covering of cloth on the courtyard for mitigating heat in summer.

This proves that thermal comfort due to the courtyards is excellent in summers, and due to this reason, no artificial means for thermal comforts are required except fans, which are used sometimes in the summer season.

\subsubsection{Natural Light}

Q: Do you feel that the courtyard is providing Natural light in all rooms?

Table 8. Natural light in all rooms

\begin{tabular}{|c|c|c|c|}
\hline \multirow{4}{*}{ Question } & Responses & Overall & Percentage \\
\hline \multirow{4}{*}{$\begin{array}{c}\text { Natural light } \\
\text { in all rooms }\end{array}$} & Strongly Disagree & 0 & $0.0 \%$ \\
\cline { 2 - 4 } & Disagree & 6 & $5.7 \%$ \\
\cline { 2 - 4 } & Undecided & 0 & $0.0 \%$ \\
\cline { 2 - 4 } & Agree & 32 & $30.2 \%$ \\
\hline
\end{tabular}

As observed in Table 8, 94.4\% agree, and 5.7\% disagree that the courtyard is providing natural light in all rooms. It is concluded that courtyards are excellent for providing natural light in all rooms.

\subsection{Behavioral Aspects of Courtyard}

Q: What kind of Activities courtyard used for?

Table 9. Use of Courtyard for sitting and dining purposes.

\begin{tabular}{|c|c|c|c|}
\hline Question & Responses & Overall & Percentage \\
\hline \multirow{4}{*}{ Siting space } & Never & 18 & $17.0 \%$ \\
\cline { 2 - 4 } & Rarely & 0 & $0 \%$ \\
\cline { 2 - 4 } & Sometimes & 20 & $18.9 \%$ \\
\cline { 2 - 4 } & Often & 9 & $8.5 \%$ \\
\cline { 2 - 4 } & Always & 59 & $55.7 \%$ \\
\hline \multirow{4}{*}{ Dining space } & Never & 46 & $43.4 \%$ \\
\cline { 2 - 4 } & Rarely & 0 & $0 \%$ \\
\cline { 2 - 4 } & Sometimes & 18 & $17.0 \%$ \\
\cline { 2 - 4 } & Often & 13 & $12.3 \%$ \\
\cline { 2 - 4 } & Always & 29 & $27.4 \%$ \\
\hline
\end{tabular}

As observed in Table 9, $64.2 \%$ of, $39.7 \%$ of respondents are using the courtyard for sitting space and dining space often or always, respectively. Hence the courtyards are utilized for siting purposes very effectively and not much used for dining space.

Table 10. Use of Courtyard for cooking space and washing utensils

\begin{tabular}{|c|c|c|c|}
\hline Question & Responses & Overall & Percentage \\
\hline \multirow{4}{*}{$\begin{array}{c}\text { Cooking } \\
\text { space }\end{array}$} & Never & 83 & $78.3 \%$ \\
\cline { 2 - 4 } & Rarely & 10 & $9.4 \%$ \\
\cline { 2 - 4 } & Sometimes & 0 & $0 \%$ \\
\cline { 2 - 4 } & Often & 5 & $4.7 \%$ \\
\hline \multirow{4}{*}{$\begin{array}{c}\text { Washing } \\
\text { utensils }\end{array}$} & Always & 8 & $7.5 \%$ \\
\cline { 2 - 4 } & Never & 21 & $19.8 \%$ \\
\cline { 2 - 4 } & Rarely & 7 & $6.6 \%$ \\
\cline { 2 - 4 } & Oometimes & 0 & $0 \%$ \\
\cline { 2 - 4 } & Olways & 77 & $0.9 \%$ \\
\hline
\end{tabular}

As observed in Table 10, 12.2\%, $73.5 \%$ of respondents are using the courtyard for cooking and washing utensils often or always, respectively. Hence the courtyards are not much used for cooking purposes and are used effectively for washing utensils purpose. 
Table 11. Use of Courtyard for washing, drying clothes and sleeping space

\begin{tabular}{|c|c|c|c|}
\hline Question & Responses & Overall & Percentage \\
\hline \multirow{4}{*}{$\begin{array}{c}\text { Washing } \\
\text { clothes }\end{array}$} & Never & 26 & $24.5 \%$ \\
\cline { 2 - 4 } & Rarely & 1 & $0.9 \%$ \\
\cline { 2 - 4 } & Sometimes & 1 & $0.9 \%$ \\
\cline { 2 - 4 } & Often & 0 & $0 \%$ \\
\hline \multirow{4}{*}{$\begin{array}{c}\text { Drying of } \\
\text { cloths }\end{array}$} & Always & 78 & $73.6 \%$ \\
\cline { 2 - 4 } & Never & 26 & $24.5 \%$ \\
\cline { 2 - 4 } & Rarely & 0 & $0 \%$ \\
\cline { 2 - 4 } & Sometimes & 4 & $3.8 \%$ \\
\hline \multirow{4}{*}{$\begin{array}{c}\text { Sleeping } \\
\text { space }\end{array}$} & Often & 6 & $5.7 \%$ \\
\cline { 2 - 4 } & Always & 70 & $66.0 \%$ \\
\cline { 2 - 4 } & Never & 64 & $60.4 \%$ \\
\cline { 2 - 4 } & Rarely & 8 & $7.5 \%$ \\
\cline { 2 - 4 } & Sometimes & 20 & $18.9 \%$ \\
\hline \multirow{4}{*}{} & Often & 3 & $2.8 \%$ \\
\hline
\end{tabular}

As observed in Table 11, 74.5\%, 71.7\%, 13.2\% of respondents are using the courtyard for washing clothes, drying clothes, and sleeping space often or always, respectively. Hence the courtyards are used for washing and drying clothes effectively and not much used for sleeping purposes.

Q: How often ceremonies /functions organized in the courtyard in a year?

Table 12. Use of Courtyard for social, cultural, religious and other family functions

\begin{tabular}{|c|c|c|c|}
\hline Question & Responses & Overall & Percentage \\
\hline \multirow{5}{*}{$\begin{array}{c}\text { Social } \\
\text { functions }\end{array}$} & Never & 32 & $30.2 \%$ \\
\hline & Rarely & 30 & $28.3 \%$ \\
\hline & Sometimes & 17 & $16.0 \%$ \\
\hline & Often & 2 & $1.9 \%$ \\
\hline & Always & 25 & $23.6 \%$ \\
\hline \multirow{5}{*}{$\begin{array}{l}\text { Cultural } \\
\text { functions }\end{array}$} & Never & 21 & $19.8 \%$ \\
\hline & Rarely & 30 & $28.3 \%$ \\
\hline & Sometimes & 24 & $22.6 \%$ \\
\hline & Often & 22 & $20.8 \%$ \\
\hline & Always & 9 & $8.5 \%$ \\
\hline \multirow{5}{*}{$\begin{array}{l}\text { Religious } \\
\text { functions }\end{array}$} & Never & 12 & $11.3 \%$ \\
\hline & Rarely & 2 & $1.9 \%$ \\
\hline & Sometimes & 33 & $31.1 \%$ \\
\hline & Often & 25 & $23.6 \%$ \\
\hline & Always & 34 & $32.1 \%$ \\
\hline \multirow{5}{*}{$\begin{array}{l}\text { Other family } \\
\text { functions }\end{array}$} & Never & 15 & $14.2 \%$ \\
\hline & Rarely & 4 & $3.8 \%$ \\
\hline & Sometimes & 21 & $19.8 \%$ \\
\hline & Often & 39 & $36.8 \%$ \\
\hline & Always & 27 & $25.5 \%$ \\
\hline
\end{tabular}

As observed in Table 12, 25.5\%, 29.3\%, 55.7\%, and $62.3 \%$ of respondents are using the courtyard for social, cultural, religious, and other functions often or always, respectively. Hence the courtyards are not used much for social and cultural functions and effectively used for religious and other functions.

Q: Which season do you prefer the courtyard most?

Table 13. Use of Courtyard in summer, winter, and monsoon.

\begin{tabular}{|c|c|c|c|}
\hline Question & Responses & Overall & Percentage \\
\hline \multirow{4}{*}{ Summer } & Never & 0 & $0 \%$ \\
\cline { 2 - 4 } & Rarely & 4 & $3.8 \%$ \\
\cline { 2 - 4 } & Sometimes & 4 & $3.8 \%$ \\
\cline { 2 - 4 } & Often & 13 & $12.3 \%$ \\
\cline { 2 - 4 } & Always & 85 & $80.2 \%$ \\
\hline \multirow{4}{*}{ Winter } & Never & 4 & $3.8 \%$ \\
\cline { 2 - 4 } & Rarely & 7 & $6.6 \%$ \\
\cline { 2 - 4 } & Sometimes & 16 & $15.1 \%$ \\
\cline { 2 - 4 } & Often & 27 & $25.5 \%$ \\
\cline { 2 - 4 } & Always & 52 & $49.1 \%$ \\
\hline \multirow{4}{*}{ Monsoon } & Never & 8 & $7.5 \%$ \\
\cline { 2 - 4 } & Rarely & 13 & $12.3 \%$ \\
\cline { 2 - 4 } & Sometimes & 33 & $31.1 \%$ \\
\cline { 2 - 4 } & Often & 34 & $32.1 \%$ \\
\cline { 2 - 4 } & Always & 18 & $17.0 \%$ \\
\hline
\end{tabular}

As observed in Table 13, 92.5\%, 74.5\%, 49.1\% of respondents are using the courtyard in summer, winter, and monsoon often or always, respectively. Hence the courtyards are used in summer and winter and not used much during monsoon.

Q: How often do you use the courtyard for activities during the day?

Table 14. Use of Courtyard in the morning, afternoon, evening and night

\begin{tabular}{|c|c|c|c|}
\hline Question & Responses & Overall & Percentage \\
\hline \multirow{4}{*}{ Morning } & Never & 0 & $0 \%$ \\
\cline { 2 - 4 } & Rarely & 5 & $4.7 \%$ \\
\cline { 2 - 4 } & Sometimes & 0 & $0 \%$ \\
\cline { 2 - 4 } & Often & 8 & $7.5 \%$ \\
\cline { 2 - 4 } Afternoon & Always & 93 & $87.7 \%$ \\
\hline & Never & 0 & $0 \%$ \\
\cline { 2 - 4 } & Rarely & 7 & $6.6 \%$ \\
\cline { 2 - 4 } & Sometimes & 11 & $10.4 \%$ \\
\cline { 2 - 4 } & Often & 38 & $35.8 \%$ \\
\hline \multirow{4}{*}{ Evening } & Always & 50 & $47.2 \%$ \\
\cline { 2 - 4 } & Never & 2 & $1.9 \%$ \\
\cline { 2 - 4 } & Rarely & 10 & $9.4 \%$ \\
\cline { 2 - 4 } & Sometimes & 1 & $0.9 \%$ \\
\cline { 2 - 4 } & Often & 22 & $20.8 \%$ \\
\hline \multirow{4}{*}{ Night } & Always & 71 & $67.0 \%$ \\
\cline { 2 - 4 } & Never & 42 & $39.6 \%$ \\
\cline { 2 - 4 } & Rarely & 15 & $14.2 \%$ \\
\cline { 2 - 4 } & Sometimes & 7 & $6.6 \%$ \\
\cline { 2 - 4 } & Often & 15 & $14.2 \%$ \\
\cline { 2 - 4 } & Always & 27 & $25.5 \%$ \\
\hline
\end{tabular}


As observed in Table 14, 95.2\%, 82.0\%,87.8\%, and $39.7 \%$ of respondents are using the courtyard in the morning, afternoon, evening, and night often or always, respectively. Hence the courtyards are used in the morning, afternoon, evening, and not so much used in the night in the present context.

Q: Do you feel that the courtyard is providing Privacy and Security?

Table 15. Privacy and Security

\begin{tabular}{|c|c|c|c|}
\hline Question & Responses & Overall & Percentage \\
\hline \multirow{4}{*}{ Privacy } & Strongly Disagree & 6 & $5.7 \%$ \\
\cline { 2 - 4 } & Disagree & 4 & $3.8 \%$ \\
\cline { 2 - 4 } & Undecided & 0 & $0.0 \%$ \\
\cline { 2 - 4 } & Agree & 5 & $4.7 \%$ \\
\cline { 2 - 4 } & Strongly Agree & 91 & $85.8 \%$ \\
\hline \multirow{4}{*}{ Security } & Strongly Disagree & 4 & $5.7 \%$ \\
\cline { 2 - 4 } & Disagree & 0 & $0.0 \%$ \\
\cline { 2 - 4 } & Undecided & 0 & $0.0 \%$ \\
\cline { 2 - 4 } & Agree & 9 & $3.8 \%$ \\
\cline { 2 - 4 } & Strongly Agree & 93 & $90.6 \%$ \\
\hline
\end{tabular}

As observed in Table 15, 85.8 \% of respondents strongly agree that the courtyard provides privacy to the residents. $90.6 \%$ of respondents strongly agree that the courtyard provides security to the residents.

Therefore, it is concluded that courtyards are excellent in providing privacy and security to the users.

\subsection{Spatial Aspects of Courtyard Design}

Q: Please state the following in terms of the physical parameters of the courtyard design.

a) Appropriateness of Location of Courtyard (Front/central/rear/side)

Table 16. Location of Courtyard

\begin{tabular}{|c|c|c|c|}
\hline Question & \multicolumn{3}{|c|}{ Location of Court Yard (Front/central/rear/side) } \\
\hline Responses & $\begin{array}{c}\text { Strongly disagree } \\
\text { /Disagree }\end{array}$ & Undecided & $\begin{array}{c}\text { Agree } \\
\text { /Strongly agree }\end{array}$ \\
\hline Front & 0 & 0 & 12 \\
\hline Central & 0 & 0 & 75 \\
\hline Rear & 4 & 0 & 11 \\
\hline Side & 0 & 0 & 4 \\
\hline Total & 4 & 0 & 102 \\
\hline
\end{tabular}

As per table $16,70.8 \%$ of respondents prefer the central location of the courtyard, but other locations are also are very much liked by people.

b) Adequacy of the size of the courtyard $(<5 \mathrm{sqm}$, $5-10$ sqm, $>10 \mathrm{sqm}$ )
Table 17. Sizes of Courtyard

\begin{tabular}{|c|c|c|c|}
\hline Question & \multicolumn{3}{|c|}{ Sizes of Court Yard $(<5 \mathrm{sqm}, 5-10 \mathrm{sqm},>10 \mathrm{sqm})$} \\
\hline Responses & $\begin{array}{c}\text { Strongly disagree } \\
\text { /Disagree }\end{array}$ & Undecided & $\begin{array}{c}\text { Agree } \\
\text { /Strongly agree }\end{array}$ \\
\hline$<5 \mathrm{sqm}$ & 6 & 0 & 48 \\
\hline $5-10 \mathrm{sqm}$ & 0 & 0 & 38 \\
\hline$>10 \mathrm{sqm}$ & 0 & 0 & 14 \\
\hline Total & 6 & 1 & 100 \\
\hline
\end{tabular}

As observed in Table 17, respondents are not having many issues for different sizes of courtyards. There might be a few issues in less than $5 \mathrm{sqm}$ size for some respondents. Hence then courtyard sizes are very appropriate in varied sizes.

c) Appropriateness of Proportions of Courtyard (length vs. breadth) and Appropriateness of Proportions of Courtyard (length /breadth vs. height)

Table 18. Proportion of Courtyard (length vs. breadth) and (length /breadth vs. height)

\begin{tabular}{|c|c|c|c|}
\hline Question & Responses & Overall & Percentage \\
\hline \multirow{2}{*}{$\begin{array}{c}\text { Proportions of } \\
\text { Court Yard } \\
\text { (length vs. } \\
\text { breadth) }\end{array}$} & $\begin{array}{c}\text { Strongly disagree } \\
\text { /Disagree }\end{array}$ & 4 & $3.8 \%$ \\
\cline { 2 - 4 } & Undecided & 0 & $0 \%$ \\
\hline \multirow{2}{*}{$\begin{array}{c}\text { Agree /Strongly } \\
\text { agree }\end{array}$} & 102 & $96.2 \%$ \\
\hline $\begin{array}{c}\text { Court Yard } \\
\text { (length } \\
\text { /breadth vs. } \\
\text { height) }\end{array}$ & $\begin{array}{c}\text { Strongly disagree } \\
\text { /Disagree }\end{array}$ & 4 & $3.8 \%$ \\
\cline { 2 - 4 } & Andecided & 0 & $0 \%$ \\
\hline \multirow{2}{*}{ Agree $/$ Strongly } & 102 & $95.2 \%$ \\
\hline
\end{tabular}

As per Table 18, respondents $96.2 \%$ agree with proportions in a plan (length vs. breadth), and $95.2 \%$ of respondents agree with proportions of the courtyards in volume (length /breadth vs. height). Hence the proportions of courtyards are very much appropriate in the plan as well as volume.

Q: Do you feel that the courtyard is providing a visual connection of ground and upper floors?

Table 19. Visual connection

\begin{tabular}{|c|c|c|c|}
\hline Question & Responses & Overall & Percentage \\
\hline \multirow{4}{*}{$\begin{array}{c}\text { Visual } \\
\text { connection } \\
\text { ground to } \\
\text { upper floors }\end{array}$} & Strongly Disagree & 4 & $3.8 \%$ \\
\cline { 2 - 4 } & Disagree & 0 & $0.0 \%$ \\
\cline { 2 - 4 } & Neutral & 0 & $0.0 \%$ \\
\cline { 2 - 4 } & Agree & 9 & $8.5 \%$ \\
\hline \multirow{4}{*}{$\begin{array}{c}\text { Visual } \\
\text { connection to } \\
\text { the street }\end{array}$} & Strongly Agree & 93 & $87.7 \%$ \\
\cline { 2 - 4 } & Strongly Disagree & 8 & $7.5 \%$ \\
\cline { 2 - 4 } & Disagree & 0 & $0.0 \%$ \\
\cline { 2 - 4 } & Neutral & 2 & $1.9 \%$ \\
\cline { 2 - 4 } & Agree & 7 & $6.6 \%$ \\
\hline \multirow{2}{*}{$\begin{array}{c}\text { Strongly Agree } \\
\text { nyy }\end{array}$} & 89 & $84.0 \%$ \\
\hline
\end{tabular}


As observed in Table 19, $96.2 \%$ of respondents agreed, and only $3.8 \%$ disagree that the courtyard provides a visual connection of the ground floor to the upper floor. The $90.6 \%$ respondents agreed, $1.9 \%$ neutral, and 7.5 disagree that the courtyard provides a visual connection to the street.

It is concluded that the courtyard provides an excellent visual connection of ground to the upper floor and the visual connection of the house to the street.

\section{Conclusions and Recommendations}

Courtyard designs were very popular throughout history due to the numerous benefits it offers to users. This typology seems to lose its importance in India due to the influence of western contemporary architecture and the new living style created after globalization and the liberalization of India in 1990. There is still a large section of the total population living in these traditional courtyard houses. It was important to investigate if these courtyard designs are still relevant for the users in the Post-Global Era. The survey has been conducted using the survey questionnaire method by administered among the residents of Pol houses. Around 106 residents of 34 traditional Pol houses have responded to the survey questionnaire form. These houses are still intact to their original character to a large extent. This data has been analyzed and discussed in this paper. The conclusion and recommendation are listed below based on the literature review and statistical analysis of responses of users.

\subsection{Environmental Aspects of Courtyard Design}

a) Courtyards are designed for thermal comfort in the critical season of summer. Users are very comfortable in summers but are not very uncomfortable during winters and monsoons. Users also feel that ventilation in all spaces through the courtyard. The users do not require desert coolers, air conditioners, as fans are sufficient for critical summers in most cases.

Recommendation 1: The design of a courtyard must create thermal comfort primarily for critical periods such as summer etc. Indeed, the design must consider thermal comfort for other seasons as well. The courtyard's design should be such that it minimizes the artificial means of cooling and heating to save energy and reduce indirect environmental pollution.

b) Courtyards are designed for diffused light in the house. Users agree that the courtyards are designed to provide diffused light in the courtyard. Due to its central location and size, the courtyards are providing natural light in the verandah, kitchen, living room, drawing room on the ground floor, and all rooms which are opening in the courtyard on the upper floor.

Recommendation 2: The courtyard's design must provide diffused natural light within the courtyard and surrounding spaces as well.

\subsection{Behavioral Aspects of Courtyard}

a) Courtyards are designed for a central location so that activities of surrounding spaces are well integrated. All the daily activities of the kitchen, verandah, living room or drawing room gets extended to the courtyard. Users are still using the courtyard for sitting, washing utensils, washing and drying clothes, and not used for cooking, dining, and sleeping purposes much in the present context.

Recommendation 3: The courtyard's design must be such that it creates a vibrant space for daily activities, while also supporting almost all activities of surrounding areas for optimal output.

b) Courtyards have been designed in such a way that all spaces around it, like the verandah, living room, drawing room, etc. become one with it for social gatherings. Household members are not using the courtyard for social and cultural functions much. It is still mostly used for religious and other family functions such as birthday parties.

Recommendation 4: The courtyard's design must integrate with other surrounding spaces to provide ample social gathering space.

c) Courtyards have been designed to allow its usage for all seasons and entire days. It is the center of all the activities. Members are using the courtyard very effectively in summers and winter, not much used in monsoon. Users are using the courtyard in the morning, afternoon, evening, and not much used in the night.

Recommendation 5: The design of the courtyard should be such that it's usable in all seasons. Special care is essential so that the courtyard is not left unused during the monsoon season.

d) Due to its central location and smaller size, the design of the courtyard should be such that it offers privacy as well as security. A staircase is always visible from the courtyard. Users entirely agree on privacy and security.

Recommendation 6: The design of the courtyard must create visual connections with other spaces to provide privacy and security.

\subsection{Spatial Aspects of Courtyards}

a) Courtyards mostly adorn a central location in houses. This location is best for environmental as well as behavioral aspects of courtyard design. Users like the central location.

b) Courtyards are designed in various sizes, but larger 
courtyards, i.e., $>10 \mathrm{sqm}$, are not available more in nos. The bigger courtyards are not good for environmental and behavioral aspects of courtyard design in the climate of Ahmedabad. Out of the remaining two sizes, $5-10 \mathrm{sqm}$ is more preferred as compared to the size of $<5 \mathrm{sqm}$.

c) Courtyards are designed with almost square size in plan. The users like all proportion of courtyards.

d) The courtyard's design provides a visual connection of the ground to upper floors and visual connection to the street. Users agree on both design aspects.

Recommendation 7: The courtyard should be designed in such a way so that the physical parameters such as location, size, proportion, visual connection to create a spatial experience, act as climate modifier and optimize utilization of space for different activities.

This study concludes that courtyards are much liked by the users in the present context and are very relevant in terms of environmental, behavioral, and spatial aspects of courtyard design. The author of this report recommends to conduct further qualitative research for the courtyard design of Pol houses. Another similar quantitative research study should also extend to different climates of the Indian states of Rajasthan, Tamil Nadu, etc.

\section{Acknowledgments}

This work is an outcome of a Ph.D. in architecture undertaken by the author. The author acknowledges the expert guidance of his Ph.D. Guide, Dr. Prabhjot Kaur. The author acknowledges the support of Punjab Technical University to provide access to excellent library resources and other infrastructural facilities.

The author acknowledges the support of all residents of Pol Houses for providing their valuable time in a survey conducted by the author.

\section{REFERENCES}

[1] Das Nibedita. Courtyards Houses of Kolkata: Bioclimatic, Typological and Socio-Cultural Study.M.Arch Thesis, Kansas State University Manhattan, Kansas.2006.pp 2-3, $15-20$.

[2] Myneni Kranti Kumar. "Courtyard as a Building Component" its Role and Application in Developing a Traditional Built form, Creating Comfort: A case of Athangudi Village, India. International Journal of Chemical, Environmental \& Biological Sciences (IJCEBS). 2013, Volume 1, Issue 4: pp 633,634 .
[3] Hussein Subhi Aiwan AL-AllAWI. A Descriptive, Analytical, and Comparative Study of Traditional Courtyard Houses and Modern Non-Courtyard Houses in Baghdad. Ph.D. in Architecture Thesis, Bartlett School of Architecture and Planning University College, University of London.1984.

[4] Pokharel K.P. Can character and communities survive in an age of globalization ?. Online available from http://www.cultureofenterprise.org/essays/06/06pokharel

[5] Mishra Suchi. Understanding the Change in Character of Courtyards. Undergraduate Architectural Dissertation.2016. Online Available from https://shuchimis hra.wordpress.com/2016/01/09/understanding-the-change-i n-character-of-courtyards/

[6] Ubbelohde M. Susan, Loisos George. The Ahmedabadi Pol House: Courtyard Strategies in a Hot-Dry/Hot-Humid Climate.University of Minnesota, Minneapolis, Mn 5545. pp.4-6. Online available from:http://coolshadow.com/resear ch/Pol_House.pdf

[7] Lambe Neeta, Dongre Alpana. Analysing Social Relevance of Spatial Organisation: A Case Study of Traditional Pol Houses, Ahmedabad, India.Asian Social Science. 2016, Vol. 12, No. 9: pp 38

[8] Kaur Amanjeet. Adaptive Reuse of Pol Houses in Ahmedabad, M.Arch. Thesis, IIT Roorkee. 2012. pp.6-7, 29-31. Online available from http://shodhbhagirathi.iitr.ac.i n:8081/jspui/handle/123456789/2012

[9] Marafa Kabir Aisha and Alibaba Halil Zafer. User Perception of Courtyard as a Thermal Regulator in Households, Famagusta, Cyprus.International Journal of Interdisciplinary Research and Innovations. 2018 March, Vol. 6, Issue 1: pp: pp1-12. Online available from https://www.researchgate.net/publication/322266324_User Perception_of_Courtyard_as_a_Thermal_Regulator_in_H ouseholds_Famagusta_Cyprus

[10] Adi Ainurzaman Jamaluddin, Hazreena Hussein, and Kauthar Md. Tahir. Satisfaction of Residents Towards Internal Courtyard Buildings. Journal of Design and Built Environment.December 2018, Vol18(2): pp 66-68. Online available from: https://www.semanticscholar.org/paper/Sati sfaction-of-Residents-Towards-Internal-Jamaludin-Hussein /6b8e6e0ffb0588b03ac790078a0c2b491e73ecdb

[11] Vakharia Mihir. Impact of Presence of Courtyard on the Thermal Characteristics of Vernacular Residential Buildings: An exploration in Hot-dry Vernacular Context of Ahmedabad. Thesis Presentation of Masters in Interior Architecture and Design, Faculty of Design, CEPT University, Ahmedabad.2012: pp 7-8, 33-34.Online available from https://dlscrib.com/queue/thesis-presentation 5a0bffa1e2b6f599388c3cb5_pdf?queue_id=5a0bffa9e2b6f $\overline{5} 63258 \mathrm{c} 4569$

[12] Bhatt Niti. Spatial role of junctions: connecting elements and their integration in traditional design, case: Pol houses, Ahmedabad.B.Arch Thesis, CEPT University, Ahmedabad. 